\title{
DE CUSATIS, Brunello (org.). Studi su Fernando Pessoa. Perugia: Edizioni dell'Urogallo, 2010
}

\author{
Dra. Opazia Chain Feres \\ Universidade Federal Fluminense - UFF \\ opazia@superig.com.br
}

(à memória de José Carlos Barcellos)

Diretor da série Ensaios luso-afro-brasileiros, da Editora Urogallo, de Perugia, Itália, Brunello De Cusatis, que assina o ensaio "Il Faust di Pessoa: una tragedia del soggetto", é quem organiza o volume Studi su Fernando Pessoa: apresenta-o ao público leitor; traduz para o italiano grande parte dos ensaios escritos em português; revê a quase totalidade de outras traduções bem como o conjunto dos ensaios. No livro, dedicado à memória de René Pedro Garay, um dos articulistas, De Cusatis insere o seu ensaio em meio à harmonia que encontra entre estudos, inéditos ou não, dos pesquisadores Adelto Gonçalves, Alfredo Margarido, Andrea Marcigliano, Fernando J. B. Martinho, Ivo Castro, Jerónimo Pizarro Jaramillo, José Blanco, Manuel G. Simões, Raúl Romero, René Pedro Garay e Vera Lúcia de Oliveira.

Já na Apresentação, o leitor apreende o tom geral do livro e fica advertido de que encontrará, examinados, gênese de mitos, gênese de mundos novos, enigmas e estranhamentos em meio aos cinco estudos que tratam de obras do Fernando Pessoa ortônimo, aos quatro que tratam de aspectos do homem Fernando Pessoa e seus escritos e aos dois que tratam de "semiheterônimos", segundo formulação de De Cusatis.

À medida que o leitor vê explorado o espólio pessoano, encontra reiteradas, negadas, postas em dúvida ou reinventadas algumas "verdades" assentes sobre o Poeta e sua obra. José Blanco, com base, principalmente, na formulação do relatório das premiações de 1934, nega que o prêmio então atribuído a Mensagem tenha tido o caráter de uma "consolação"; Alfredo Margarido flagra um Pessoa que "se preparava para ser poeta em língua 
inglesa, escrevendo provisoriamente em português"; Brunello De Cusatis traça o percurso do empenho profundo do poeta-alquimista, que escreve e reescreve seu Fausto por 25 anos; Ivo Castro, com as lentes da Crítica Textual, percorre trechos problemáticos da decifração de Pessoa; Manuel Simões percebe o Poeta engajado numa rebelião dos insatisfeitos, rebelião que, ao longo da História, toma diferentes formas; a ideia do poeta-louco estaria na raiz da formulação dos heterônimos, segundo o texto de Jerónimo Pizarro para quem a "inquietação política" seria fonte de toda a obra pessoana, não apenas de Mensagem; um poeta em busca de si mesmo parece prevalecer no ensaio de Vera Lúcia de Oliveira; com Raúl Romero e René Pedro Garay o leitor lembra que não é de hoje o hibridismo de gênero; Fernando J. B. Martinho identifica no poeta bucólico apresentado como real, alquimista avant la lettre, a função sacerdotal de guia de poetas desde a época de sua criação até os nossos dias.

A leitura do ensaio sobre o Fausto pessoano, personagem sem saída, proposto e reproposto desde que a Historia von D. Johann Fausten foi publicada (1587), recolhendo um mito que se formara já em vida de Johann Fausten (1480-1540) - mas personagem que Pessoa queria português e vivente já no século XIII - mostra, em vários outros momentos do livro, a importância, nos escritos de Pessoa, dos séculos XV-XVI, quando ocorreu uma mudança de rota no pensamento da Cristandade.

Para quem se formou em ambiente romântico, admirou alguns -ismos e guardou do anarquista o estereótipo daquilo que poderia ser, para o ensaio em questão, um anarquista "plebeu”, ler "L'anarca e il potere occulto dell'oro. Riflessioni sparse su Il banchiere anarchico di Fernando Pessoa" causa impacto considerável. O ensaio aponta para um encontro entre alquimia, política e economia, numa linhagem que teria começado no Renascimento italiano e chegaria a nosso 
tempo. Com o paradoxo como chave de leitura - paradoxo entendido como "um modo de indagar a verdade que subjaz à aparência cambiante das formas" (p. 66, trad. nossa), Andrea Marcigliano serve-se de escritos econômicos de Pessoa, de quanto disse Ezra Pound sobre a função da guerra para o poeta de ontem e a função da economia para o poeta de hoje, e esboça um quadro dessa personagem instigante, alquimista bem sucedido com DNA nietzscheano, senhor do mistério dos processos do devir e vontade de poder plenamente realizada, que é o banqueiro 'anarca': um aristocrata radical, que alcança a liberdade espiritual através do domínio perfeito do dinheiro.

Afins ao paradoxo, explorado no texto de Marcigliano, o oxímoro e a ambiguidade são instrumentos apontados por Adelto Gonçalves, instrumentos estes que se anunciam bastante rentáveis para indagar a expressão das profundezas alquímicas na linguagem concisa da poesia pessoana.

Seja a partir do ensaio de um autor, seja de outro, o leitor pode encontrar tantíssimos estímulos aos próprios estudos sobre Pessoa e sobre outros autores que beberam nas mesmas fontes esotéricas ou no mesmo ambiente cultural em que bebeu Pessoa.

Estudioso das ciências ocultas e empenhado na obra perene da atualização do ouro alquímico, o Poeta insere-se nos debates de fim de século com "interesse e ironia" - com distanciamento aristocrático - o que o mantém aberto a outras possibilidades, dentro de perspectivas mais amplas.

Se a Alquimia é a chave de todas as ciências e parece dar o tom, com sucesso pleno, ao volume aqui tratado, é lícito aplaudir a retomada desse saber como algo precioso para orientar não só o futuro dos estudos pessoanos mas também o inventário das consequências políticas dos rumos abertos pelo esoterismo retomado no século XIX e começo do XX; e

Se em Mensagem, o Poeta, com domínio pleno do simbólico, a "certeza da ressurreição do desejado", a "autoridade deputada", organiza um 
futuro politicamente encoberto é analogamente correto identificar, subjacente a Mensagem, uma política profunda, eficaz e duradoura porque molda a vida exterior a partir do engajamento das almas às quais se destina - engajamento na admiração de um D. Sebastião tomado como imagem visível de algo invisível: um ícone, ou como figura daquele que virá cumpri-la. 